\title{
Mengembangkan Kemampuan Berfikir Kritis Melalui Metode Pembelajaran Improve
}

\author{
Mujib \\ ${ }^{1}$ UIN Raden Intan Lampung; mujibzahra@gmail.com
}

\begin{abstract}
This study aims to find out how to develop students' critical thinking skills through IMPROVE learning methods. This type of research is a quasi experimental design study. The research design used was pretest-posttest experimental control group design. The research sample was not selected randomly (nonrandomly assigned groups). Data collection used is using the test method. The instrument used for data collection is a test of critical thinking skills. Data analysis using a different test, namely t-test and two-way ANAVA test. The results were obtained, showing that the development of critical thinking skills mathematically, groups of students who obtained IMPROVE learning were better than groups of students who received conventional learning. In the group of students who obtained IMPROVE learning, the upper category students had better mathematical critical thinking skills than the middle category and lower category students, while the improvement in the lower critical thinking ability of students in the lower category was better than the middle category students. There is an interaction between learning factors with the category of students' abilities there is an increase in mathematical critical thinking skills.
\end{abstract}

Keywords: Critical Thinking Ability and IMPROVE Learning Methods

\begin{abstract}
Abstrak
Penelitian ini bertujuan untuk mengetahui bagaimana pengembangan kemampuan berpikir kritis matematis siswa melalui metode pembelajaran IMPROVE. Jenis penelitian ini adalah penelitian quasi eksperiment design. Desain penelitian yang digunakan adalah pretestposttest eksperimental control group design. Pengambilan sampel penelitian tidak dipilih secara random (nonrandomly assigned groups). Pengumpulan data yang digunakan adalah menggunakan metode tes. Instrumen yang digunakan untuk pengambilan data adalah tes kemampuan berpikir kritis. Analisis data dengan menggunakan uji beda yaitu uji-t dan uji ANAVA dua jalur. Hasil penelitian diperoleh, menunjukkan bahwa pengembangan kemampuan berpikir kritis matematis, kelompok siswa yang memperoleh pembelajaran IMPROVE lebih baik dibandingkan kelompok siswa yang memperoleh pembelajaran Konvensional. Pada kelompok siswa yang memperoleh pembelajaran IMPROVE, siswa kategori atas memiliki peningkatan kemampuan berpikir kritis matematis yang lebih baik dibandingkan siswa kategori tengah dan siswa kategori bawah, sedangkan peningkatan kemampuan berpikir kritis matematis siswa kategori bawah lebih baik dibandingkan siswa kategori tengah. Terdapat interaksi antara faktor pembelajaran dengan kategori kemampuan siswa terdapat peningkatan kemampuan berpikir kritis matematis.
\end{abstract}

Kata Kunci: Kemampuan Berpikir Kritis dan Metode Pembelajaran IMPROVE

\section{PENDAHULUAN}

Pendidikan tidak akan terlepas dari proses belajar dan pembelajaran. Pembelajaran adalah proses interaksi yang terjadi antara guru dengan siswa yang melibatkan berbagai 
komponen yang saling mempengaruhi (Sari, 2015; Purwanto, 2012). Pada dasarnya terdapat hubungan antar berpikir ktitis dengan belajar (Harvey, 2002). Proses pembelajaran di kelas pada umumnya hanya diarahkan pada kemampuan siswa untuk menghafal informasi tanpa melibatkan keterampilan berpikir. Salah satu aspek penting dalam matematika adalah kemampuan berpikir kritis (Zetriuslita, Ariawan, dan Nufus 2016). Pentingnya kemampuan berpikir kritis diharapkan agar siswa dapat memecahkan persoalan-persoalan dalam kehidupan yang dinamis (Istianah 2013). Rendahnya kemampuan berpikir kritis siswa saat ini merupakan suatu permasalahan yang tidak kalah penting dalam pendidikan matematika. Perubahan paradigma dalam pembelajaran matematika membawa dampak pada penekanan pendekatan yang berorientasi pada perubahan dan keterlibatan siswa dalam proses pembelajaran yang berfokus pada pencapaian pengembangan keahlian yang lebih bersifat adaptif (Kilpatrick et al., 2001; Verschaffel et al., 2007). Pada lain pihak keahlian adaptif lebih menekankan pandangan kemampuan siswa dalam memecahkan tugas-tugas matematis secara efisien, kreatif, dan fleksibel menggunakan strategi pemecahan yang berbeda dan bermakna (Baroody \& Dowker, 2003). Konsep, sifat, ide matematis dan proses yang berawal dari paling sederhana hingga kompleks merupakan kegiatan yang berkaitan dengan kegiatan matematis (doing math), sedangkan soal atau tugas yang berkenaan dengan doing math merupakan tugas matematis (mathematical task) (Del Mas, 2002). Memunculkan berbagai ide atau gagasan-gagasan yang bersifat asli (original), luwes (flexible) dan lancar (fluent) dalam pengambilan kesimpulan serta memikirkan kemungkinan penyelesaian lainnya akan dilakukan oleh siswa saat mereka melakukan proses berpikir untuk menyelesaikan masalah matematika berkaitan dengan analogi atau perbedaan, mengenali keterkaitan atau hubungan antar konsep, kemampuan mengulang atau mengingat, menyadari adanya hubungan sebab akibat. Pembelajaran yang inovatif sangat diperlukan dalam mengembangkan kualitas kemampuan berpikir siswa (Wiley, 2009). Sebagai upaya memfasilitasi siswa agar memiliki kemampuan berpikir kritis yang berkembang, yaitu dengan pemiliham metode pembelajaran yang tepat. Metode pembelajaran yang dapat diterapkan yaitu metode pembelajaran IMPROVE.

Metode pembelajaran IMPROVE merupakan metode yang setiap kata dalam akronimnya merupakan langkah pembelajaran. Menurut Kramerski (Mevarech \& Armany, 2008) penjabaran dari akronim di atas mempresentasikan semua tahap dalam metode ini, yaitu: mengantarkan konsep baru, pertanyaan metakognitif, latihan, mereviu dan mengurangi kesulitan, penguasaan materi, melakukan verifikasi, dan pengayaan. Metode pembelajaran IMPROVE adalah metode pembelajaran yang lebih mengedepankan pengembangan keterampilan metakognitif dan kemampuan berpikir kritis. Hal ini tercermin dalam langkah pembelajaran metode pembelajaran IMPROVE yaitu metacognitive questioning. Langkah dalam pembelajaran tersebut merupakan pengembangan proses berpikir siswa lewat kesadaran akan apa yang siswa pahami sehingga secara tak langsung akan berakibat pada kemampuan berpikir kritis siswa. Metode pembelajaran IMPROVE merupakan singkatan dari semua langkah-langkah dalam pengajaran Kramerski (Mevarech \& Armany, 2008), yaitu:

\section{Introducing The New Concepts}

Mengantarkan konsep baru dalam metode pembelajaran IMPROVE berbeda dengan mengantarkan konsep baru pada pembelajaran tradisional. Pada pembelajaran dengan 
menggunakan metode tradisional, seorang guru mengantarkan konsep baru dengan cara ceramah di depan kelas dan para siswa mendengarkan apa yang dikatakan guru.

\section{Metacognitive Questioning}

Guru memberikan pertanyaan-pertanyaan metakognitif yang berupa apa, mengapa, bagaimana. Menurut Kramerski (Mevarech \& Armany, 2008), pertanyaan-pertanyaan tersebut dapat berupa: pertanyaan pemahaman masalah, pertanyaan tentang pengembangan hubungan antara pengetahuan lalu dan sekarang, pertanyaan menggunakan strategi penyelesaian masalah yang tepat dan pertanyaan refleksi pada saat menyelesaikan masalah. Pertanyaan metakognitif yang dapat diajukan kepada siswa menurut Mevarech \& Kramarski antara lain:

\section{a) Pertanyaan Pemahaman}

Pertanyaan ini berhubungan dengan teori yang menjadi materi dalam pembelajaran. Misalnya, mengenai apa keseluruhan masalah ini?. Berhubungan dengan pengetahuan teori mengenai masalah yang akan dipecahkan. Contohnya: seorang guru memberikan permasalahan kepada siswa mengenai suatu materi, setelah itu guru bertanya kepada siswa, "Apa masalah ini?". Pada proses ini, metakognitif siswa berjalan. Siswa berfikir, untuk menjawab pertanyaan yang diberikan oleh guru.

\section{b) Pertanyaan Koneksi}

Pertanyaan koneksi merupakan pertanyaan mengenai apa yang siswa dapat sekarang dengan apa yang telah didapatnya dahulu. Misalnya, "Apakah masalah sekarang sama atau berbeda dari pemecahan masalah yang telah Anda lakukan di masa lalu?".

\section{c) Pertanyaan Strategi}

Pertanyaan strategi berkaitan dengan solusi-solusi yang akan diajukan siswa untuk memecahkan permasalahan yang dihadapinya. Pertanyaan ini merangsang siswa untuk mencari solusi yang paling tepat atau alternatif-alternatif solusi lain untuk memecahkan suatu masalah. Misalnya,"Strategi apa yang cocok untuk memecahkan masalah tersebut, mengapa?".

\section{d) Pertanyaan Refleksi}

Pertanyaan ini mendorong siswa untuk mempertimbangkan cara atau strategi yang telah diajukannya. Misalnya, "Apakah strategi itu merupakan solusi yang masukakal untuk memecahkan masalah ini?".

\section{Practicing}

Setelah memberikan pertanyaan-pertanyaan yang membangun pengetahuan siswa, siswa diberi pertanyaan metakognitif, selanjutnya siswa diajak untuk berlatih memecahkan masalah secara langsung. Guru memberikan latihan kepada siswa berupa soal-soal atau permasalahan.

\section{Reviewing and Reducing Difficulties}

Pada tahap ini guru mencoba melakukan reviuew terhadap kesalahan-kesalahan yang dihadapi siswa dalam memahami materi dan memecahkan soal-soal atau permasalahan. Selanjutnya guru memberikan solusi untuk menghadapi kesulitan yang ada.

\section{Obtaining Mastery}

Setelah melakukan pembelajaran, guru memberikan tes kepada siswa. Tes ini bertujuan untuk mengetahui penguasaan materisiswa. 


\section{Verification}

Setelah dilakukan tes dan mengetahui hasilnya, kemudian dilakukan identifikasi untuk memisahkan siswa mana yang mencapai batas kelulusan dan siswa mana yang belum mencapai batas kelulusan.

Perancangan metode pembelajaran IMPROVE yang baik dapat meningkatkan keefektifan dalam meningkatan kualitas pembelajaran (Upal, 2005). Metode pembelajaran yang memungkinkan untuk dikembangkan di tingkat SMP adalah pembelajaran yang mampu mengembangkan berpikir kritis siswa (Syafei, 2015). Berpikir kritis menekankan pada siswa akan perlunya merencanakan strategi penyelesaian masalah dari berbagai sumber, mencetuskan banyak gagasan, membandingkan strategi solusi dengan pengalaman atau teori terdahulu. Mengkonstruksi gagasan dan membuat kesimpulan perlu dilakukan siswa saat strategi telah dipilih oleh siswa. Pengembangan suatu gagasan yang dimiliki siswa akan dapat ditambah atau diperinci secara detil suatu obyek, gagasan, atau situasi. Setelah melalui tahapan tersebut siswa akan memperoleh solusi kemudian, solusi tersebut perlu evaluasi dengan diperiksa dan dikembangkan strategi alternatif (Baybutt, 2016). Pendapat lain dikemukakan oleh Noer (2010) bahwa, kemampuan pemecahan masalah matematis dalam kerangka kurikulum matematika Singapura digambarkan sebagai sebuah segilima beraturan dengan masing-masing sisi menggambarkan komponen yang mendukungnya, yakni: (1) Konsep, (2) Pemrosesan (termasuk di dalamnya keterampilan berpikir dan heuristik), (3) Metakognisi (termasuk di dalamnya kemandirian belajar), (4) Sikap, dan (5) Keterampilan. Apabila kelima komponen ini dikuasai dengan baik maka kemampuan pemecahan masalah matematis dapat dicapai. Pada masa transisi siswa mulai dapat dilatih untuk berpikir hipotesis, proporsional, evaluatif, analitis, sintesis, kritis dan logis serta mampu memahami konsep secara abstrak dan jika dilihat dari perkembangan mental tersebut siswa SMP sudah mulai mampu untuk diajak berpikir ketingkat penalaran yang lebih tinggi yaitu kearah berpikir kritis bukan hanya ditingkat berpikir dasar saja, sehingga alangkah lebih baiknya bila pembelajaran yang dilaksanakan di SMP disesuaikan dengan taraf berpikir siswa. Tahap akhir dari metode pembelajaran IMPROVE adalah melakukan pengayaan terhadap siswa yang belum mencapai batas kelulusan atau belum menguasai materi. Hal ini dilakukan dengan kegiatan remedial. Dalam melaksanakan pembelajaran dengan metode pembelajaran IMPROVE, guru pertama kali harus memperkenalkan konsep baru pada siswanya dengan menggunakan tehnik pertanyaan metakognitif. Kemudian siswa dilatih untuk menggunakan 4 jenis pertanyaan yang ditunjukan pada diri sendiri (Mevarech\& Fridkin, 2006) yaitu: 1). Pemahaman terhadap soal, 2). Koneksi soal, 3). Strategi dalam menyelesaikan soal, dan 4). Refleksi soal.

Berdasarkan penelitian yang sudah ada sebelumnya, dalam penelitian ini yang memberikan pengaruh positif terhadap pengembangan kemampuan berpikir kritis melalui banyak model yang diterapkan yaitu, pengembangan kemampuan berpikir kritis melalui pembelajaran; Scientific Approach, Inkuiri Terbimbing, REACT, PBL, Berbasis Masalah, Reciprocal Teaching, PjBL, Blended Learning, CTL (Sutarto, 2014; Kurniawati, 2014; Wulandari, 2015; Malahayati, 2015; Sari D. S., 2015; Adiwijaya, 2016; Hikmah, 2016; Alfi, 2016; Wakijo, 2016). Pengembangan kemampuan berpikir kritis dengan keterbaruan model pembelajaran yang diterapkan dengan menggunakan metode pembelajaran IMPROVE 
dengan tujuan untuk mengetahui bagaimana pengembangan kemampuan berpikir kritis matematis siswa melalui metode pembelajaran IMPROVE.

\section{METODE PENELITIAN}

Jenis penelitian ini adalah penelitian quasi eksperiment design. Desain penelitian yang digunakan adalah pretest-posttest eksperimental control group design. Sampel pada penelitian ini terdiri dari dua kelas, yaitu kelas Eksperimen dan kelas Kontrol. Pengambilan sampel penelitian tidak dipilih secara random (nonrandomly assigned groups), karena penelitian yang memberikan perlakuan kepada subjek penelitian untuk diketahui pengaruh dari perlakuan yang diberikan dengan tidak mengelompokkan subjek secara acak dan menerima keadaan subjek apa adanya. Pengumpulan data yang digunakan adalah menggunakan metode tes. Instrumen yang digunakan untuk pengambilan data adalah tes kemampuan berpikir kritis. Adapun prosedur rancangan penelitian disajikan pada Gambar 1.

Kelompok Eksperimen

Kelompok Kontrol

\section{Keterangan:}
$\mathrm{X}$
: Metode Pembelajaran IMPROVE
O : Tes Yang Diberikan Untuk Mengetahui Kemampuan Berpikir Kritis Siswa (pretest- posttest)

Uji prasyarat untuk uji coba normalitas menggunakan uji One Sampel Kolmogorov Smirnov dengan taraf signifikasi $5 \%$ dengan hipotesis yang diuji adalah:

$H_{\circ}$ : Sebaran data berdistribusi normal

$H_{a}$ : Sebaran data berdistribusi tidak normal

Sebaran data dikatakan berdistribusi normal jika $L_{\text {hitung }}<L_{\text {tabel }}$ maka $H_{\circ}$ diterima, namun jika $L_{\text {hitung }} \geq L_{\text {tabel }}$ maka $H_{0}$ ditolak. Uji prasyarat untuk uji coba homogenitas menggunakan uji statistik Compare Mean Independent Samples Test dengan taraf signifikasi $5 \%$ dengan hipotesis yang diuji adalah:

$H_{\circ}$ : Sebaran data adalah homogen

$H_{a}$ : Sebaran data tidak homogen

Sebaran data dikatakan homogen jika $X^{2}{ }_{\text {hitung }} \leq X^{2}{ }_{\text {tabel }}$ maka maka $H_{o}$ diterima, namun jika $X_{\text {hitung }}^{2} \geq X_{\text {tabel }}^{2}$ maka $H_{o}$ ditolak. Analisis data dengan menggunakan uji beda yaitu uji-t dan uji ANAVA dua jalur.

\section{HASIL PENELITIAN DAN PEMBAHASAN}

Tes hasil pretes kelompok pembelajaran IMPROVE dan kelompok pembelajaran Konvensional. Hasil skor pretes kemampuan berfikir kritis matematis siswa diperoleh sebelum pembelajaran diberikan, baik pada kelompok pembelajaran IMPROVE maupun kelompok pembelajaran Konvensional. Berdasarkan pengolahan terhadap skor pretes, diperoleh skor minimum $\left(X_{\min }\right)$, skor maksimum $\left(X_{\text {maks }}\right)$, skor rerata () , persentase $(\%)$ dan simpangan baku (s). Adapun hasil deskriptif data tes kemampuan berpikir kritis disajikan pada Tabel 1. 
Tabel 1. Hasil Pretes Kelompok Pembelajaran IMPROVE dan Kelompok Pembelajaran Konvensional

\begin{tabular}{|c|c|c|c|c|c|c|c|}
\hline \multirow{2}{*}{ Kelompok } & \multirow{2}{*}{$\begin{array}{l}\text { Jmh } \\
\text { siswa }\end{array}$} & \multirow{2}{*}{$\begin{array}{c}\text { Skor } \\
\text { Ideal }\end{array}$} & \multicolumn{5}{|c|}{ Pretes } \\
\hline & & & $X_{\min }$ & $X_{\text {maks }}$ & $\bar{X}$ & $\%$ & $s$ \\
\hline $\begin{array}{l}\text { Pembelajaran } \\
\text { IMPROVE }\end{array}$ & 32 & & 0,00 & 12,00 & 5,062 & 11,111 & 3,047 \\
\hline $\begin{array}{l}\text { Pembelajaran } \\
\text { Konvensional }\end{array}$ & 31 & 36 & 8,00 & 28,00 & 16,063 & 10,676 & 4,989 \\
\hline
\end{tabular}

Berdasakan Tabel 1 dapat dilihat adanya perbedaan hasil pretes pada deskriptif data tes kemampuan berpikir kritis pada kelompok pembelajaran IMPROVE dan kelompok pembelajaran Konvensional. Pada kelompok pembelajaran IMPROVE diperoleh skor minimum 0,00 sedangkan pada kelompok pembelajaran Konvensional diperoleh skor 8,00. Kelompok pembelajaran IMPROVE diperoleh skor maksimum 12,00 sedangkan pada kelompok pembelajaran Konvensional diperoleh skor 28,00. Rerata kelompok pembelajaran IMPROVE diperoleh skor 5,062 sedangkan pada kelompok pembelajaran Konvensional diperoleh skor 16,063. Presentase kelompok pembelajaran IMPROVE diperoleh sebesar 11,111\% sedangkan pada kelompok pembelajaran Konvensional diperoleh sebesar 10,676 \%. Simpangan baku kelompok pembelajaran IMPROVE diperoleh skor 3,047 sedangkan pada kelompok pembelajaran Konvensional diperoleh skor 4,989.

Sebelum melakukan uji parametris pada pretes terlebih dahulu dilakukan uji asumsi diantaranya: uji normalitas dan homogenitas. Uji normalitas untuk mengetahui apakah sebaran data berdistribusi normal atau tidak dan uji homogenitas untuk mengetahui sama tidaknya variansi dua buah distribusi data. Adapun hasil data uji normalitas dapat dilihat pada Tabel 2.

Tabel 2. Hasil Uji Normalitas Skor Pretes Kemampuan Berpikir Kritis Matematis Siwa Kelompok Pembelajaran IMPROVE dan Kelompok Pembelajaran Konvensional

\begin{tabular}{ccc}
\hline IMPROVE & $\begin{array}{c}\text { Pembelajaran } \\
\text { IMPRolajaran }\end{array}$ & $\begin{array}{c}\text { Pembelansional } \\
\text { Konvension }\end{array}$ \\
\hline Kolmogorov-Smirnov Z & 32 & 31 \\
Asymp.Sig.(2-tailed) & 0,477 & 0,774 \\
\hline
\end{tabular}

Tabel 2 menunjukkan hasil uji normalitas terhadap kemampuan berpikir kritis matematis pada kelompok pembelajaran IMPROVE dan kelompok pembelajaran Konvensional dengan taraf signifikasi $5 \%$. Berdasarkan hasil data uji normalitas pada pretes dengan metode pembelajaran IMPROVE tes kemampuan berpikir kritis matematis diperoleh nilai signifikasi (sig) sebesar 0,977 dan sedangkan metode pembelajaran Konvensional tes kemampuan berpikir kritis matematis diperoleh nilai signifikasi (sig) sebesar 0,587. Pada taraf signifikasi $5 \%=0,05$, teryata nilai signifikansi kedua sampel tesebut lebih besar dari $\alpha$, dapat disimpulkan $H_{0}$ diterima. Jadi kedua kelompok data skor pretes kemampuan berpikir kritis matematis tersebut adalah berdistribusi normal. 
Hasil pretes uji homogenitas terhadap kemampuan berpikir matematis pada metode pembelajaran IMPROVE dan metode pembelajaran Konvensional, dapat dilihat pada Tabel 3.

Tabel 3. Hasil Uji Homogenitas Varians Skor Pretes Kemampuan Berpikir

Kritis Matematis Siswa Kelompok Pembelajaran IMPROVE dan Kelompok Pembelajaran Konvensional

\begin{tabular}{ccc}
\hline$F$ & Sig & Kesimpulan \\
\hline 0,312 & 0,578 & Homogen \\
\hline
\end{tabular}

Tabel 3 menunjukkan hasil uji homogenitas varians terlihat nilai Levene Statistik ( $F$ ) sebesar 0.312 dengan nilai signifikansi sebesar 0,578. Nilai signifikasi tersebut lebih besar dari taraf signifikasi $(\alpha)=0,05$, sehingga dapat disimpulkan bahwa HO diterima yang menyatakan varians populasi kedua kelompok data adalah homogen. Hasil perhitungan uji statistik Compare Mean Independent Samples Test dapat dilihat dapa Tabel 4.

Tabel 4. Hasil uji perbedaan Dua rerata pretes Kemampuan Berpikir Kritis Matematis Siswa Kelompok Pembelajaran IMPROVE dan Kelompok Pembelajaran Konvensional

\begin{tabular}{ccc}
\hline $\mathrm{t}$ & $\mathrm{Df}$ & Sig \\
\hline$-0,154$ & 61 & 0,878 \\
\hline
\end{tabular}

Berdasarkan Tabel 4 di atas dapat diketahui bahwa nilai signifikasi (Sig) sebesar 0,878 lebih besar dari nilai $\alpha=0,05$, berarti kedua kelompok data skor pretes kemampuan berpikir kritis matematis ini memiliki rerata kemampuan awal berpikir kritis matematis yang tidak berbeda, sehingga kedua kelompok kelas yaitu kelas pembelajaran IMPROVE dan kelas pembelajaran Konvensional memiliki kemampuan yang sama.

Hasil skor postes kemampuan berfikir kritis matematis siswa merupakan skor yang diperoleh setelah pembelajaran diberikan baik pada kelompok pembelajaran IMPROVE maupun kelompok pembelajaran Konvensional. Berdasarkan pengolahan terhadap skor pretes, diperoleh skor minimum $\left(X_{\text {min }}\right)$, skor maksimum $\left(X_{\text {maks }}\right)$, skor rerata () , persentase $(\%)$ dan simpangan baku (s) sebagaimana pada Tabel 5.

Tabel 5. Hasil Postes Kelompok Pembelajaran IMPROVE dan Kelompok Pembelajaran Konvensional.

\begin{tabular}{|c|c|c|c|c|c|c|c|}
\hline \multirow[t]{2}{*}{ Kelompok } & \multirow{2}{*}{$\begin{array}{l}\text { Jmh } \\
\text { siswa }\end{array}$} & \multirow{2}{*}{$\begin{array}{l}\text { Skor } \\
\text { Ideal }\end{array}$} & \multicolumn{5}{|c|}{ Pretes } \\
\hline & & & $X_{\min }$ & $X_{\text {maks }}$ & $\bar{X}$ & $\%$ & $s$ \\
\hline $\begin{array}{l}\text { Pembelajaran } \\
\text { IMPROVE }\end{array}$ & 32 & 36 & 8,00 & 28,00 & 16,0623 & 44,6175 & 4,989 \\
\hline Pembelajaran & 31 & & 4,00 & 27,00 & 13,2258 & 36,7383 & 6,520 \\
\hline
\end{tabular}

Tabel 5 menunjukkan perbedaan rerata hasil postes pada kelompok pembelajaran IMPROVE dan kelompok pembelajaran Konvensional. Pada kelompok pembelajaran IMPROVE diperoleh skor minimum 8,00 sedangkan pada kelompok pembelajaran Konvensional diperoleh skor 4,00. Kelompok pembelajaran IMPROVE diperoleh skor maksimum 28,00 sedangkan pada kelompok pembelajaran Konvensional diperoleh skor 27,00. Rerata kelompok pembelajaran IMPROVE diperoleh skor 16,0623 sedangkan pada 
kelompok pembelajaran Konvensional diperoleh skor 13,2258. Presentase kelompok pembelajaran IMPROVE diperoleh sebesar 44,6175 \% sedangkan pada kelompok pembelajaran Konvensional diperoleh sebesar 36,7383 \%. Simpangan baku kelompok pembelajaran IMPROVE diperoleh skor 4,989 sedangkan pada kelompok pembelajaran Konvensional diperoleh skor 6,520.

Sebelum melakukan uji parametris pada postes terlebih dahulu dilakukan uji asumsi diantaranya: uji normalitas dan homogenitas. Uji normalitas untuk mengetahui apakah sebaran data berdistribusi normal atau tidak dan uji homogenitas untuk mengetahui sama tidaknya variansi dua buah distribusi data. Untuk melihat sebuah data normal atau tidak, pada data postes dilakukan dengan pengujian statistik One-Sampel Kolmogorov-Smirnov menggunakan SPSS for Windows versi 17. Adapun hasil data uji normalitas dapat dilihat pada Tabel 6.

Tabel 6. Hasil uji Normalitas Skor Postes Kemampuan Berpikir Kritis Matematis Siwa Kelompok Pembelajaran IMPROVE dan Kelompok Pembelajaran Konvensional

\begin{tabular}{ccc}
\hline Pembelajaran IMPROVE & $\begin{array}{c}\text { Pembelajaran } \\
\text { Konvensional }\end{array}$ \\
\hline Kolmogorov-Smirnov Z & 32 & 31 \\
Asymp.Sig.(2-tailed) & 0,730 & 0,850 \\
\hline
\end{tabular}

Tabel 6 menunjukkan hasil uji normalitas terhadap kemampuan berpikir kritis matematis pada kelompok pembelajaran IMPROVE dan kelompok pembelajaran Konvensional dengan taraf signifikasi $5 \%$. Berdasarkan hasil data uji normalitas pada postes dengan metode pembelajaran IMPROVE tes kemampuan berpikir kritis matematis diperoleh nilai signifikasi (sig) sebesar 0,661 dan sedangkan metode pembelajaran Konvensional tes kemampuan berpikir kritis matematis diperoleh nilai signifikasi (sig) sebesar 0,465. Pada taraf signifikasi $5 \%=0,05$, teryata nilai signifikansi kedua sampel tesebut lebih besar dari $\alpha$, dapat disimpulkan $H_{0}$ diterima. Jadi kedua kelompok data skor postes kemampuan berpikir kritis matematis tersebut adalah berdistribusi normal. Hasil postes uji homogenitas terhadap kemampuan berpikir matematis pada metode pembelajaran IMPROVE dan metode pembelajaran Konvensional, dapat dilihat pada Tabel 7.

Tabel 7. Hasil Uji Homogenitas Varians Skor Postes Kemampuan Berpikir Kritis Matematis Siswa Kelompok Pembelajaran IMPROVE dan Kelompok Pembelajaran Konvensional

\begin{tabular}{ccc}
\hline$F$ & Sig & Kesimpulan \\
\hline 5,010 & 0,029 & Homogen \\
\hline
\end{tabular}

Tabel 7 menunjukkan hasil uji homogenitas varians terlihat nilai Levene Statistik ( $F$ ) sebesar 5,010 dengan nilai signifikansi sebesar 0,029. Nilai signifikasi tersebut lebih besar dari taraf signifikasi $(\alpha)=0,05$, sehingga dapat disimpulkan bahwa $H_{0}$ diterima yang menyatakan varians populasi kedua kelompok data adalah homogen. Hasil perhitungan uji statistik Compare Mean Independent Samples Test dapat dilihat dapa Tabel 8.

Tabel 8. Hasil uji perbedaan Dua Rerata Postes Kemampuan Berpikir Kritis Matematis Siswa Kelompok Pembelajaran IMPROVE dan 
Kelompok Pembelajaran Konvensional

\begin{tabular}{ccc}
$\mathrm{t}$ & $\mathrm{Df}$ & Sig.(2-tailed) \\
1,943 & 61 & 0,057 \\
\hline
\end{tabular}

Berdasarkan Tabel 8, dapat diketahui bahwa nilai signifikasi (Sig.2-tailed) sebesar 0,057 lebih besar dari nilai $\alpha=0,05$, sehingga dapat disimpulkan bahwa hipotesis nol yang menyatakan tidak terdapat perbedaan antara rerataan kedua kelompok ditolak. Berarti kemampuan berpikir kritis matematis siswa yang memperoleh pembelajaran IMPROVE secara statistik lebih baik dibandingkan dengan kemampuan berpikir kritis matematis siswa yang memperoleh pembelajaran Konvensional.

Peningkatan kemampuan berpikir kritis matematis yang dicapai oleh siswa dilihat dengan menggunakan data gain ternormalisasi, sehinga dapat dianalisis dalam penelitian ini adalah gain yang telah ternormalkan. Suherman dan Kusumah (1990) menyatakan bahwa proses penentuan kelompok atas dan kelompok bawah diambil 54\% yaitu $27 \%$ untuk kelompok atas dan $27 \%$ untuk kelompok bawah dan $56 \%$ sisanya termasuk kelompok tengah. Rerata gain ternormalisasi merupakan gambaran peningkatan kemampuan berpikir kritis matematis baik dengan pembelajaran IMPROVE maupun dengan pembelajaran Konvensional.

Tabel 9. Rerata $\mathbf{N}$-gain Kemampuan berpikir Kritis Matematis

\begin{tabular}{cccccc} 
Pembelajaran & $\begin{array}{c}\text { Katagori } \\
\text { Siswa }\end{array}$ & $\begin{array}{c}\text { Rerata } \\
\text { (Mean) }\end{array}$ & $\begin{array}{c}\text { Katagori } \mathbf{N}- \\
\text { gain }\end{array}$ & $\begin{array}{c}\text { Simpangan } \\
\text { Baku }\end{array}$ & $\begin{array}{c}\text { Jumlah } \\
\text { Siswa }\end{array}$ \\
\hline \multirow{3}{*}{ IMPROVE } & Atas & 0,557 & Sedang & 0,186 & 9 \\
& Tengah & 0,340 & Sedang & 0,141 & 14 \\
& Bawah & 0,145 & Rendah & 0,121 & 9 \\
& Total & 0,346 & Sedang & 0,187 & 32 \\
\hline \multirow{3}{*}{ Konvensional } & Atas & 0,499 & Sedang & 0,130 & 8 \\
& Tengah & 0,231 & Sedang & 0,106 & 15 \\
& Bawah & 0,076 & Rendah & 0,169 & 8 \\
& Total & 0,260 & Sedang & 0,136 & 69
\end{tabular}

Berdasarkan Tabel 9, diperoleh rerata $\mathrm{N}$-gain berpikir kritis matematis siswa menggunakan pembelajaran IMPROVE lebih tinggi 0,346 dari rerataan $\mathrm{N}$-gain kemampuan berpikir kritis matematis siswa yang menggunakan pembelajaran Konvensional. Katagori siswa kelampok atas, tengah dan bawah pada pembelajaran IMPROVE memiliki rerata Ngain kemampuan berpikir kritis tergolong sedang. Pada kelompok atas rerata $\mathrm{N}$-gain kemampuan berpikir kritis matematis menggunakan pembelajaran IMPROVE $(0,557)$ lebih tinggi disbandingkan dengan rerata $\mathrm{N}$-gain kemampuan berpikir kritis matematis yang menggunakan pembelajaran konvensional $(0,499)$. Pada siswa kelompok bawah, rerata $\mathrm{N}$ gain kemampuan berpikir kritis matematis yang menggunakan pembelajaran IMPROVE $(0,145)$ lebih tinggi dibandingkan dengan rerata $\mathrm{N}$-gain kemampuan berpikir kritis matematis yang menggunakan pembelajaran konvensional $(0,076)$.

Dari kesimpulan di atas masih perlu dilakukan pengujian statistik untuk mengetahui signifikansi kebenaran kesimpulan tersebut. Pengujian statistik yang digunakan adalah uji 
ANOVA dua jalur. Sebelum dilakukan pengujian ANOVA dua jalur terlebih dahulu dilakukan uji normalitas dan uji homogenitas terhadap data $\mathrm{N}$-gain sebagai uji prasyarat ANOVA dua jalur. Hasil uji normalitas statistik One Sampel Kolmogorov Smirnov dengan menggunakan bantuan SPSS for windows versi 18 dapat dilihat pada Tabel 10.

Tabel 10. Uji Normalitas Distribusi Data $\mathbf{N}$-gain Kemampuan Berpikir Kritis Matematis Siwa Berdasakan Pembelajaran

\begin{tabular}{lcc}
\hline & $\begin{array}{c}\text { N-gain Pembelajaran } \\
\text { IMPROVE }\end{array}$ & $\begin{array}{c}\text { N-gain Pembelajaran } \\
\text { Konvensional }\end{array}$ \\
\hline Kolmogorov-SmirnovZ & 0,518 & 0,826 \\
Asymp Sig.(2-tailed) & 0,951 & 0,503
\end{tabular}

Tabel 10 menunjukkan hasil pengujian statistik diperoleh nilai signifikansi sebesar 0,951 untuk N-gain kemampuan berpikir kritis matematis siswa pada kelompok pembelajaran IMPROVE yang diberi pembelajaran Konvensional 0,503 untuk N-gain kemampuan berpikir kritis matematis. Sehingga kedua kelompok kemampuan berpikir kritis matematis berdasarkan pembelajaran tersebut berdistribusi normal.

Tabel 11. Uji Normalitas Distribusi Data $\mathbf{N}$-gain Kemampuan berfikir Kritis

Matematis Siswa berdasarkan Kategori Siswa

\begin{tabular}{cccc}
\hline & $\begin{array}{c}\text { N-gain } \\
\text { Kategori Atas }\end{array}$ & $\begin{array}{c}\text { N-gain Kategori } \\
\text { Tengah }\end{array}$ & $\begin{array}{c}\text { N-gain Kategori } \\
\text { Bawah }\end{array}$ \\
\hline Kolmogorov-SmirnovZ & 0,749 & 0,969 & 0,495 \\
Asymp Sig.(2-tailed) & 0,629 & 0,305 & 0,967
\end{tabular}

Tabel 11 menunjukkan hasil pengujian statistic nilai signifikansi sebesar 0,629 untuk skor n-gain kemampuan berpikir kritis matematis siswa pada kelompok siswa dengan kategori atas, pada kelompok siswa dengan kategori tengah 0,305 dan siswa pada kelompok dengan kategori bawah 0,967. Sehingga kedua kelompok kemampuan berpikir kritis matematis berdasarkan pembelajaran tersebut berdistribusi normal.

Tabel 12. Uji Normalitas Distribusi Data $\mathbf{N}$-gain Kemampuan Berpikir Kritis Matematis Siswa Berdasarkan Pembelajaran dan Kategori Pengetahuan Siswa

\begin{tabular}{ccccccc}
\hline & $\begin{array}{c}\text { N-gain } \\
\text { IMPROVE } \\
\text { Kategori } \\
\text { Atas }\end{array}$ & $\begin{array}{c}\text { N-gain } \\
\text { IMPROVE } \\
\text { Kategori } \\
\text { Tengah }\end{array}$ & $\begin{array}{c}\text { N-gain } \\
\text { IMPROVE } \\
\text { Kategori } \\
\text { Bawah }\end{array}$ & $\begin{array}{c}\text { N-gain } \\
\text { Konvesional } \\
\text { IMPROVE } \\
\text { Kategori } \\
\text { Atas }\end{array}$ & $\begin{array}{c}\text { N-gain } \\
\text { Konvesiona } \\
\text { I IMPROVE } \\
\text { Kategori } \\
\text { Tengah }\end{array}$ & $\begin{array}{c}\text { Nonvesiona } \\
\text { I IMPROVE } \\
\text { Kategori } \\
\text { Bawah }\end{array}$ \\
\hline $\begin{array}{c}\text { Kolmogorov } \\
\text {-SmirnovZ } \\
\text { Asymp } \\
\text { Sig.(2- }\end{array}$ & 0,645 & 0,808 & 0,433 & 0,618 & 0,622 & 0,411 \\
tailed) & 0,799 & 0,531 & 0,992 & 0,840 & 0,835 & 0,996 \\
\hline
\end{tabular}

Tabel 12 menunjukkan diatas hasil pengujian statistik diperoleh nilai singnifikasi (sig) sebesar 0,799 untuk skor $\mathrm{N}$-gain kemampuan bepikir kritis matematis siswa pada kelompok siswa yang diberi pembelajaran IMPROVE dengan katagori atas, 0,531 untuk skor N-gain 
kemampuan berpikir kritis matematis kelompok IMPROVE dengan katagori tengah, dan 0,992 untuk skor $\mathrm{N}$-gain kemampuan berpikir kritis matematis kelompok IMPROVE dengan katagori bawah. 0,840 untuk skor $\mathrm{N}$-gain kemampuan bepikir kritis matematis siswa pada kelompok siswa yang diberi pembelajaran konvensional dengan katagori atas, 0,835 untuk skor $\mathrm{N}$-gain kemampuan berpikir kritis matematis kelompok konvensional dengan katagori tengah, dan 0,996 untuk skor $\mathrm{N}$-gain kemampuan berpikir kritis matematis kelompok konvensional dengan katagori bawah. Pada taraf singnifikasi $\alpha=0,05$ nilai singnifikasi keenam sampel tersebut lebih besar dari nilai $\alpha$ sehingga dapat disimpulkan bahwa hipotesis nol yang menyatakan sampel $\mathrm{N}$-gain berasal dari distribusi normal. Setelah menguji kenormalan data, kedua data diuji homogenitasnya untuk melihat apakah kedua data tersebut memiliki varians yang sama atau homogen digunakan uji Homogenety of Variavces (levene Statistic).

Tabel 13. Hasil Uji Homogenitas Varians Skor $\mathbf{N}$-gain Kemampuan Berpikir Kritis Matematis Siswa

\begin{tabular}{ccc}
\hline $\mathrm{F}$ & Sig. & Kesimpulan \\
\hline 0,218 & 0,642 & Homogen
\end{tabular}

Tabel 13 menunjukkan hasil uji homogenitas varians terlihat nilai Levene Statistic (F) adalah sebesar 0,218 dengan nilai signifikansi sebesar 0,642. Nilai signifikasi tersebut lebih besar dari taraf singnifikasi $\alpha=0,05$ sehinga dapat disimpulkan bahwa hipotesis nol yang menyatakan varians populasi keenam kelompok data adalah homogen. Artinya keenam kelompok data gain kemampuan bepikir kritis matematis memiliki varians yang homogen.

Selanjutnya kelompok data N-gain dengan statistik ANOVA dua jalur ini untuk melihat pengaruh langsung dilakukan dengan SPSS for Windaws versi 18 menggunakan General Linear Model (GLM) - Univariate yang dapat dilihat pada Tabel 14.

Tabel 14. Hasil Uji ANOVA Dua Jalur N-gain Kemampuan Berpikir Kritis Matematis Menurut Pembelajaran dan Kategori Siswa

\begin{tabular}{cccccc}
\hline Source & $\begin{array}{c}\text { Type III } \\
\text { sum of } \\
\text { squares }\end{array}$ & df & $\begin{array}{c}\text { Mean } \\
\text { Square }\end{array}$ & F & Sig \\
\hline Corrected Model & $1,627^{\text {a }}$ & 5 & .325 & 60.766 & .000 \\
Intercept & 5,591 & 1 & 5.591 & 1044.014 & .000 \\
Pembelajaran & .092 & 1 & .092 & 17.108 & .000 \\
Kategori-siswa & 1.499 & 2 & .750 & 139.957 & .000 \\
Pembelajaran* & .008 & 2 & .004 & .783 & .000 \\
Kategori-Siswa & & & & & \\
Error & 0.305 & 57 & .005 & & \\
Total & 7.745 & 63 & & & \\
Corrected Total & 1.932 & 62 & & & \\
\hline
\end{tabular}

R Squared $=, 842$ (Adjusted R Squared $=, 828$ ) 
Berdasarkan Tabel 14 dipeoleh signifikasi (sig) sebesar 0,000 nilai signifikasi tersebut lebih kecil dari nilai $\alpha=0,05$ sehingga terdapat interaksi antara faktor metode pembelajaran dan katagori pengetahuan siswa terhadap kemampuan berpikir kritis matematis. Secara grafik, interaksi antara faktor pembelajaran dan faktor kategori siswa dapat dilihat pada Gambar 1.

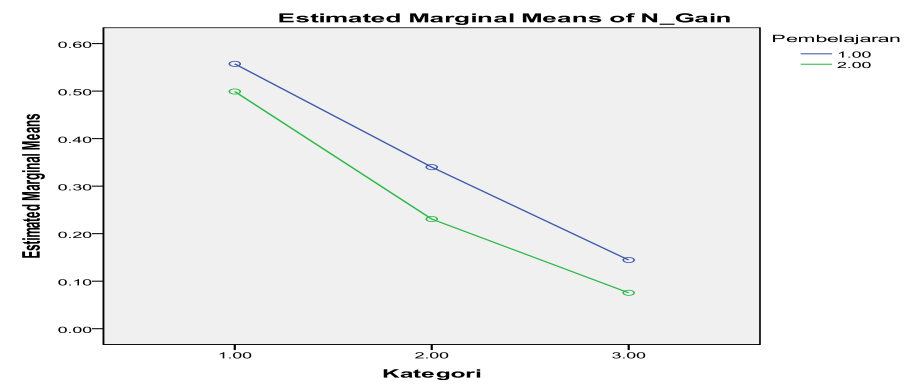

\section{Gambar 1. Interaksi Antara Faktor Pembelajaran dan Faktor Kategori Siswa}

Gambar 1 menunjukan adanya perbedaan kemampuan berpikir kritis matematis yang signifikan antara siswa kelampok atas, kelompok tengah dan kelompok bawah pada siswa yang memperoleh pembelajaran IMPROVE. Gambar tersebut menujukkan bahwa kemampuan berpikir kritis matematis siswa yang memperoleh pembelajaran IMPROVE lebih baik pada siswa dengan kategori pengetahuan awal siswa atas dan bawah dibandingkan siswa yang memperoleh pembelajaran konvensional. Pada pembelajaran IMPROVE, kemampuan berpikir kritis matematis siswa menunjukkan perbedaan yang besar. Pada gambar tersebut menunjukan interaksi antara faktor metode pembelajaran dengan kategori pengetahuan siswa. Maka pembelajaran IMPROVE dan kategori pengetahuan siswa secara bersama-sama dapat mempengaruhi peningkatan kemampuan berpikir kritis matematis siswa.

\section{SIMPULAN DAN SARAN}

Berdasarkan hasil analisis dan pengolahan data yang didukung dengan landasan teori serta mengacu pada tujuan penelitian, maka dapat disimpulkan bahwa: pengembangan kemampuan berpikir kritis matematis kelompok siswa yang memperoleh metode pembelajaran IMPROVE lebih baik dibandingkan kelompok siswa yang memperoleh pembelajaran Konvensional. Pada siswa yang memperoleh pembelajaran IMPROVE, siswa kategori atas memiliki peningkatan kemampuan berpikir kritis yang lebih baik dibandingkan dengan siswa kategori tengah dan siswa kategori bawah, sedangkan peningkatan kemampuan berpikir kritis matematis siswa kategori bawah lebih baik dibandingkan siswa kategori tengah sehingga terdapat perbedaan peningkatan kemampuan berpikir kritis antara siswa kelompok atas, kelompok tengah, dan kelompok bawah pada siswa yang memperoleh kedua metode pembelajaran. Terdapat interaksi antara faktor pembelajaran dan kategori kemampuan siswa terhadap peningkatan kemampuan berpikir kritis matematis. Ada beberapa saran untuk penelitian selanjutnya; dapat mencari metode-metode pembelajaran lain yang lebih berpengaruh terhadap kemampuan berpikir kritis matematis siswa dan mencoba menggunakan metode yang sama ataupun metode-metode pembelajaran lain dengan mencari pengaruh lain maupun menambah tinjauan penelitian 
terhadap kemampuan afektif peserta didik. Semoga penelitian ini dapat bermanfaat dan menjadi sumber rujukan ataupun referensi penelitian selanjutnya.

\section{DAFTAR PUSTAKA}

Adiwijaya, H. E. (2016). Penerapan Pembelajaran Reciprocal Teaching Berbantuan Peta Konsep Untuk Meningkatkan Kemampuan Berpikir Kritis Siswa Pada Pembelajaran Biologi. Jurnal Pendidikan:Teori, Penelitian, dan Pengembangan , 1 (12), 2379-2387.

Alfi, C. S. (2016). Pengaruh Pembelajaran Geografi Berbasis Masalah Dengan Blended Learning Terhadap Kemampuan Berpikir Kritis Siswa SMA. Jurnal Pendidikan: Teori, Penelitian, dan Pengembangan , 1 (4), 597-602.

Baroody, A. J, \& Dowker,A (2003) The Development of Arithmetic Concepts and Skills: Constructing Adaptive Expertise. Mahwah, N.J: Lawrence Erlbaum Associates.

Baybutt, P. (2016). A Framework for Critical Thinking in Process Safety Management. American Institute of Chemical Engineers , 1-4.

DelMas, R. C (2002).initial fractions learning by frouth- and the fifth-grades student: Acomparison of the effect of using commercial curricula with the effect of using the rational project curriculum. Journal for Research in Mathematics Education,33(2),111-144

Harvey, B. S. (2002). Critical Thinking. A Companion to The Victorian Novel , 181-193.

Hikmah, N. E. (2016). Pengaruh Strategi Project Based Learning (PjBL) Terhadap Kemampuan Berpikir Kritis Siswa Kelas XI IPA Pada Materi Koloid. Jurnal Pendidikan: Teori, Penelitian, dan Pengembangan , 1 (11), 2248-2253.

Istianah, Euis. 2013. "Meningkatkan Kemampuan Berpikir Kritis dan Kreatif Matematik dengan Pendekatan Model Eliciting Activities (MEAS) Pada Siswa SMA." Infinity Journal 2 (1): 43-54.

Kilpatrick, J., Swafford, J., \& Findell, B. (2001). Adding it up. Helping children lern mathematics. Washington, D. C.: National Academy Press.

Kurniawati, I. D. (2014). The Effect Of Peer Instruction Integrated Guided linquiry Learning On Concepts Acquistion and Critical Thingking Of Students. Jurnal Pendidikan Fisika Indonesia , 10, 36-46.

Malahayati, E. N. (2015). Hubungan Keterampilan Metakognitif dan KemampuanBerpikir Kritis dengan Hasil Belajar Biologi Siswa SMA dalamPembelajaran Problem Based Learning (PBL). Jurnal Pendidikan Sains , 3 (4), 178-185.

Purwanto, S. M. (2012). Inplementasi Permainan Monopoli Fisika Sebagai Media Pembelajaran Dalam Pembelajaran Kooperatif Tipe TGT Untuk Meningkatkan Prestasi 
Belajar dan Mengetahui Profil Kemampuan Berpikir Kritis Siswa SMP. Jurnal Pengajaran MIPA , 17 (1), 69-76.

Sari, D. S. (2015). Pengembangan Multimedia Berbasis Masalah Untuk Meningkatkan Motivasi Belajardan Kemampuan Berpikir Kritis Siswa. Jurnal Inovasi Pendidikan IPA, 1 (2), 153-166.

Sari, J. R. (2015). Penerapan Pembelajaran Biologi Berbasis SAINS Budaya Lokal Kesenian Sintren Pada Konsep Spermatophyta Untuk Meningkarkan Keterampilan Berpikir Kritis Siswa SMAN 1 Ciwaringin. Scientiae Educatia , 5 (1), 1-12.

Sutarto, R. d. (2014). Investigation Dengan Scientific Portofolio Terhadap Kemampuan Implementasi Group Approach Berbasis Berpikir Kritis Matematis. Unnes Journal of Mathematics Education , 3 (3), 220-230.

Syafei, I. (2015). Pengembangan Model Pembelajaran Untuk Meningkatkan Kemampuan Berpikir Kritis Siswa. Psympathic: Jurnal Ilmiah Psikologi , 2 (2), 133-140.

Upal, M. A. (2005). Learning To mprove Plan Quality. Department of Electrical Engineering and Computer Science, 21 (4), 440-461.

Wakijo, S. S. (2016). Implementasi Pendekatan Contextual eaching and Learning (CTL) Terhadap Kemampuan Berpikir Kritis Siswa. Jurnal Pendidikan Ekonomi UM Metro , 4 (2), 43-49.

Wiley, J. d. (2009). The Nature and Value Of Critical Thinking. Deciding What to Do and Believe, 1-37.

Wulandari, N. C. (2015). Pembelajaran Model REACT Dengan Pendekatan Saintifik Terhadap Kemampuan Berpikir Kritis dan Kerjasama. Unnes Journal of Mathematics Education, 4 (3), 265-274.

Zetriuslita, Rezi Ariawan, dan Hayatun Nufus. 2016. "Analisis Kemampuan Berpikir Kritis Matematis Mahasiswa Dalam Menyelesaikan Soal Uraian Kalkulus Integral Berdasarkan Level Kemampuan Mahasiswa." Infinity Journal 5 (1): 56-65. 